\title{
Case study: what did Rafael Correa say? Comparing political attention across 10 years of the Ecuadorian president's discourses
}

\author{
Pablo Ruiz Aguirre 1 \\ 1 International University of Ecuador / Faculty of Law, Loja - Ecuador
}

\begin{abstract}
The "citizen revolution" was a political project executed mainly between 2007 and 2016 by the former president of the Republic of Ecuador, Rafael Correa Delgado, under the paradigm of $21^{\text {st }}$ century socialism. The main characteristic of this project was to introduce a new political agenda to the country that was differentiated from past agendas, by focusing on issues such as the recognition of new rights, improvements to education, instituting a new economic model, and strengthening government and sovereignty, among others. Under this context, this work aims to analyze the political attention of the ex-president, explaining why some issues are more important than others, and why they varied over time. Based on a conceptual framework that takes ideas from the agenda-setting theory, the areas on which the political agenda concentrates are measured by the Shannon entropy index, and its various changes are explained as the results of preferences, institutional factors, and external events. The analysis is based on extensive database analyses of 10 years (covering Rafael Correa's presidency) of government speeches, which are coded according to the methodology of the Comparative Agendas Project (CAP). To the best of our knowledge, this paper is the first work to apply the CAP methodology in Ecuador.
\end{abstract}

Keywords: agenda setting; issue agendas; executive speeches; political attention; Rafael Correa.

\section{Estudo de caso: 0 que Rafael Correa disse? Comparando a atenção política em 10 anos dos discursos do presidente equatoriano}

A "revolução cidadã" foi o projeto político realizado principalmente pelo ex-presidente da República do Equador, Rafael Correa Delgado, sob o paradigma do socialismo do século XXI entre 2007 e 2016. Esse projeto foi caracterizado por estabelecer uma nova agenda política no país, diferenciando-se do passado, concentrando-se em questões como reconhecimento de novos direitos, melhoria da educação, proposta de um novo modelo econômico e fortalecimento do governo e da soberania, entre outros. Nesse contexto, este trabalho tem como objetivo analisar a atenção política na agenda do ex-presidente da república, explicar por que algumas questões são mais importantes que outras e por que há variações nelas ao longo do tempo. Com base em uma estrutura conceitual que retira idéias da teoria da definição da agenda, a concentração da agenda política é medida através do índice de entropia de Shannon e as diferentes mudanças nele são explicadas como resultado de preferências, atritos institucionais e eventos externos. A análise é baseada em extensas bases de dados de 10 anos de discursos governamentais (presidência de Rafael Correa), codificados de acordo com a metodologia do Projeto de agendas comparativas (PAC). Até onde sabemos, este é o primeiro trabalho que aplica essa metodologia no Equador.

Palavras-chave: agenda; agendas temáticas; discursos executivos; atenção política; Rafael Correa. 


\section{Estudio de caso: ¿qué dijo Rafael Correa? Comparando la atención política en 10 años de discursos del presidente ecuatoriano}

La "revolución ciudadana" fue el proyecto político ejecutado principalmente por el expresidente de la República del Ecuador, Rafael Correa Delgado, bajo el paradigma del socialismo del siglo XXI, entre 2007 y 2016. Este proyecto se caracterizó por establecer una nueva agenda política en el país, diferenciándose de las pasadas, enfocándose en temas como el reconocimiento de nuevos derechos, mejora de la educación, propuesta un nuevo modelo económico y el fortalecimiento del gobierno y la soberanía entre otros. Bajo este contexto, este trabajo tiene como objetivo analizar la atención política de la agenda del expresidente de la república, explicar por qué algunos temas son más importantes que otros y por qué hay variaciones en ellos a lo largo del tiempo. Con base en un marco conceptual que toma ideas de la teoría del establecimiento de la agenda, se mide la concentración de la agenda política a través del índice de entropía de Shannon y se explican los diferentes cambios en ella a raíz de las preferencias, las fricciones institucionales y los eventos externos. El análisis se basa en extensas bases de datos sobre 10 años de discursos del gobierno (presidencia de Rafael Correa), que están codificados de acuerdo con la metodología del Proyecto de Agendas Comparadas (PAC). Por lo que conocemos, este es el primer trabajo que aplica esta metodología en Ecuador.

Palabras clave: establecimiento de agenda; agendas temáticas; discursos presidenciales; atención política; Rafael Correa.

\section{INTRODUCTION}

A political agenda consists of an inventory of issues, situations and problems that a society considers essential at specific times and locations (Kingdon, 1984). Many such issues are considered by the legislature, others are promoted by the media, and still others by current governments. Regarding the latter, the question is: how can a president set the political agenda in a world where information is abundant and not everything can be considered important? One of the ways in which such agenda-setting can be understand is by studying the official speeches of the head of state. However, how should such a dataset be analyzed? The answer is to address the content from an agendasetting perspective-that is, the study of which issues manage to enter the political agenda and why (Bachrach \& Baratz, 1962; Cobb \& Elder, 1980; Downs, 1972; Kingdon, 1984; McCombs \& Shaw, 1972; Schattschneider, 1960). The Comparative Agendas Project (CAP) "enables scholars, students, policy-makers and the media to investigate trends in policy-making across time and between countries" (www.comparativeagendas.net). While CAP started in the US, it now includes jurisdictions in both the US and Europe within its ambit (John, 2006), and recently, CAP has been extended to Latin American countries, including Brazil, Colombia and Ecuador, providing new avenues for future comparative research.

To the best of our knowledge, this paper represents the first application of CAP methodology to the study of Ecuadorian politics. We apply it here to analyze the political attention represented by the agenda of the ex-president Rafael Correa Delgado to explain why some issues are more important than others and why they vary over time. The study was conducted using the collective speeches given by Rafael Correa between 2007 and 2016. Three are acceptance speeches given after having won elections, while the rest are accountability speeches, a difference that will be analyzed further later in the paper. Rafael Correa's collected speeches constitute the longest known data 
series of executive attention in Ecuador, comprising 10 speeches over 10 years with 3,297 units of analysis (quasi-sentences)

The first question to consider here is: What were the most important policy agenda issues of the Ecuadorian president Rafael Correa? The agenda-setting approach provides unconventional explanations regarding the variations in how and why various issues enter the political agenda beyond simple policy preferences (Baumgartner, Jones, \& Wilkerson, 2011). These issues exceed what political discourse prefers to focus on as content; they can, for example, be introduced by strategy, by political calculation, or by knowledge of specific issues supporting other factors that determine the policy agenda. Hence, the second question is why do policy agendas change over the years. The underlying assumption is that an agenda and its changes can be explained by policy preferences, institutional factors, focusing events, and new information flows.

From a comparative perspective, several related studies have already been conducted. For example, studies of the Australian political agenda through the analysis of governors-general (GG) speeches of determined that the discourse is not incremental; instead, changes are introduced into the agenda by new events (Dowding, Hindmoor, Iles, \& John, 2010). Likewise, in the UK, "The Speech from the Throne" was studied to consider the selective emphases by governing parties and issue intrusion, and it was found that speech reflects the strengths of the issues espoused by the major political parties in Britain and that these are also affected by external shocks (Jennings, Bevan, \& John, 2011). Other comparative studies of speeches from countries such as the Netherlands, UK and Denmark sought to determine whether a change in party government results in a change in the government's issue agenda. The results showed that elections do not explain many of the change in executive policy agendas (Mortensen et al., 2011). In contrast, a study analyzing the effects of the core functions of government on the diversity of the executive agendas of various European countries and the US found that agendas issues tend to concentrate on or relate to classical state functions, such as government operations, economy and defense (Jennings et al., 2011). Finally, scholars focused on the evolution of the prioritization of issues in the USA and Spain and found that variations in agenda concentration coincide with specific events (Chaqués-Bonafont, Palau, Muñoz, \& Wilkerson, 2008). The contribution of this paper is clearly empirical. That is, it has been undertaken for the first time in Ecuador to verify some of the theories and hypotheses raised by the CAP community and to answer the established research questions. The preliminary results show that the concentration of the agenda effectively coincides with traditional state functions and show a preference for nonconservative issues such as civil rights and minority issues. However, a peculiar characteristic evident in the Ecuadorian case that has not been identified heretofore in other studies is that in this case, a large concentration of attention emerges focused on what was this paper determines as "rhetoric". This is based on a unit of analysis (quasi-sentence) that could not be codified according to the proposed methodology because it did not include policy content but instead pure rhetoric-motivational phrases, stories, and metaphors, among others. This is interesting because it raises questions not considered by the current agenda studies, such as: Does this commonly occur in Latin American presidential regimes? Does it occur only in Latin American countries? Is this content perhaps related to populist regimes? 
The remainder of this paper is organized as follows: Section 2 is dedicated to relating this case study to the existing literature on the agenda-setting approach. Section 3 describes the data and methodology used. Section 4 is devoted to explaining the changes in issue prioritization in the presidential agenda. Finally, preliminary conclusions are proposed in Section 5.

\section{BACKGROUND OF THE AGENDA SETTING APPROACH}

Governments normally receive exacerbated information that tries to define a given reality, just as issues compete to enter and gain a place in the political agenda. The agenda setting approach seeks to study the issues that do manage to enter the political agenda-how they manage this and why. Such concepts have been extensively analyzed from both practical and theoretical viewpoints (Bachrach \& Baratz, 1962; Baumgartner \& Jones, 2010; Cobb \& Elder, 1980; Downs, 1972; Jones \& Baumgartner, 2005; Kingdon, 1984; McCombs \& Shaw, 1972; Schattschneider, 1960).

The political process does not necessarily involve order and planning; in fact, it is generally better explained through its disorder and the absence of planning. Preferences constitute only one variable that explains political results (Baumgartner et al., 2011; Green-Pedersen, 2007; Walgrave, Varone, \& Dumont, 2006), meaning that attention to different issues in presidential speeches is driven not only by party preferences but also by institutional factors, new flows of information, and sudden changes, such as an economic crisis (Chaqués-Bonafont, Baumgartner, \& Palau, 2015). Consequently, these three political agenda explanatory variables will be analyzed and related from a theoretical viewpoint to explain the Ecuadorian political agenda.

First, as many authors have already emphasized, policy preferences are important in explaining why issues enter the political agenda (Boix, 1998; Canes-Wrone, 2001), and in the Ecuadorian case, these preferences can be found in the speeches of the head of the state. Therefore, speeches can be treated as a source of information regarding the presidential policy agenda (Breeman et al., 2009; Jennings \& John, 2009; Jennings et al., 2011; John, Larsen, \& Liu, 2006; John, Jennings, \& Bevan, 2010; Mortensen et al., 2009). Subsequently, what preferences do presidents express in a speech? A politician might use a speech for various purposes: to make political commitments, to set priorities or highlight previous ones, to respond to public problems before, during and after an election campaign, or to persuade the electorate. Consequently, speeches reflect not only real political priorities but also partisan preferences. Therefore, some topics may be highlighted in the discourse to provide an illusion of interest or priority, while others might be ignored due to political calculation (Dowding et al., 2010). The first type denotes issues that the politician prefers to say, while the second type denotes issues the politician prefers not to discuss.

In this sense, policies are grounded in party or actor preferences. This is supported by the studies on issue ownership that have stated, for example, that parties try to capitalize on an agenda regarding those issues on which they are most competent (Budge \& Hofferbert, 1990; Klingemann, Hofferbert, \& Budge, 1994). Additionally, a large number of studies in the CAP community have used issue ownership theory to explain why political elites pay attention to some issues and not others (Green \& Jennings, 2012; Green \& Jennings, 2019; Green-Pedersen \& Mortensen, 2010). Issue ownership theory was originally developed to explain why political parties pay attention to particular issues 
during electoral campaigns. Political parties are considered to emphasize issues for which they have a reputation for greater competence and for which the reputations of their opponents are less well regarded (Budge \& Farlie, 1983; Petrocik, 1996). According to this theory, it should be expected that left-leaning parties focus more on issues related to welfare, equal rights, and the environment, where they are perceived by the public to perform better, while right-leaning parties are expected to pay more attention to issues such as the economy, taxes, and crime, where they have a reputation for good performance. From this situation, a question arises: Can these ideas be applied to the study of a president's agenda in a presidential system?

In other respects, in the studies of the Australian policy agenda, discourse was determined as signaling the political intentions of an incoming government (Dowding et al., 2010). Can Rafael Correa's speeches be determined to have this characteristic? In addition, is it possible that Correa's speeches potentially exhibit selective emphasis or issue ownership (Budge \& Farlie, 1983; Carmines \& Stimson, 1989; Petrocik, 1996), through which his party “Alianza País" promotes self-benefiting issues (Budge \& Farlie, 1983) for which they already enjoy a good reputation? (Petrocik, 1996).

Related to this topic, studies of England's policy agendas with respect to the throne's speech, for example, determined that the agenda-setting role of the speech reflects the issue strengths of the key political parties. This means that conservative governments tend to pay less attention to civil rights and minority issues, social issues and government operations but historically assign more weight to international affairs than do other governments (Jennings et al., 2011). Following these ideas-and because speeches are agendas characterized by high saliency used to send messages to the electorate-it can be expected that the Ecuadorian president should emphasize issues that are of interest to the voters of the party in power. This means that, having been elected as president of the left wing or (as Correa qualified his regime), part of the "socialism of the 21 st century", and needing to respond to his voters, he should highlight issues such as, for example, rights, social policy and education within his political agenda. Therefore, does Correa pay more attention to civil rights and minority issues, social issues and government operations than to international relations issues as Jennings et al. (2011) stated?

Second, the political agenda, as stated above, does not depend exclusively on the president's preferences, whether partisan, ideological or otherwise, because it also depends on institutional factors, which impose significant limitations on the plans and performances of actors involved in policymaking processes (Baumgartner \& Jones, 2015). Therefore, presidential preferences matter. Through speeches, messages are conveyed to the voters, and consequently, the expectation is that they should place greater emphasis on issues that produce an electoral advantage. However, regardless of preferences, there are some issues that every president must address. As the literature has shown us, the key state functions significantly explain the diversity of attention (Kingdon, 1984). Additionally, some issues are taken more seriously by governments than others (Jennings et al., 2011). These characteristics can be outlined with reference to classic theories of the state (Hobbes, 1651; Locke, 1689; Rousseau, 1762), in which the central commitments of the state are to protect its borders, manage its external relations, ensure the general welfare of its people and maintain the government apparatus. In addition, 
some studies highlight that most government agendas are inclined to focus on the economy, defense and international affairs (Cohen, 1999; Edwards \& Barrett, 2000).

Likewise, some core executive functions exist that have the ability to concentrate the agenda. Accordingly, a comparative analysis of issue diversity in executive agendas of various European countries and the United States over the postwar period showed that governments agendas tend to focus on core issues such as the economy, government operations, defense and international affairs; all of which correspond to core state functions. The study also suggested that when the core functions of government are less important on the agenda, executives pursue a more diverse agenda, but when core functions of government are highly important on the agenda, executives follow a less diverse agenda, concentrating their attention on issues related to classic state functions (Jennings et al., 2011). The question that arises here is whether the same types of changes occur in Ecuador, considering that it has a different governmental structure than do European parliamentary systems-and of course, it has a different historical and contextual reality compared with northern countries such as the US.

Third, unplanned events and flows of new information are also significant factors in describing how and why new issues enter the political agenda (Baumgartner \& Jones, 2010, 2015; Chaqués-Bonafont et al., 2015; Kingdon, 1984). Environmental problems, natural catastrophes, corruption scandals, economic crises, political scandals or any new publication or information that was not initially considered can drastically change the government's political agenda. Thus, for example, the earthquake that occurred on the Ecuadorian coast in April 2016 profoundly changed not only the government's political agenda from a symbolic point of view but also its substantive agenda.

It is important to emphasize that latent issues can climb to the top of the policy agenda, possibly due to crises or the appearance of new situations (Baumgartner \& Jones, 2010; Baumgartner, Jones, \& MacLeod, 1998; Jones \& Baumgartner, 2005; Jones, Sulkin, \& Larsen, 2003). Along this line, studies of GG speeches in Australia found that political agendas could be separated from established issues in GG speeches more radically as events occur (Dowding et al., 2010). Does this also occur in Ecuador? That is, does the content of the speeches of the ex-president of Ecuador depend on external or unplanned events not obviously considered and affect the convergence of these same issues in the years that the speeches were given?

Other works, considering the fact that the function of the executive agenda is to respond to external information or shocks such as wars or constitutional emergencies (Jennings et al., 2011) and that issue intrusion is incorporated as new information used by policy makers make decisions, (Jones \& Baumgartner, 2005) show that external shocks control the length of the speech, typically decreasing it. This means that exogenous events can control the focus of attention or its concentration in a speech. However, again, is this also true in the Ecuadorian case? In other words, did external events change the political agenda of the speeches of ex-president Correa?

In summary, the causes of attention increases or decreases regarding a specific issue or group of issues do not necessarily have a single explanatory variable; instead, several explanatory variables can coexist or not coexist simultaneously in time. Did variables such as preferences, institutional factors and external events help to build the executive agenda of Ecuador during the 10-year term 
of Rafael Correa's presidency? These questions provided in this section will be answered positively or negatively in this study.

\section{DATA AND METHODOLOGY}

From an agenda-setting perspective, official executive speeches possess some interesting attributes. A president giving an official speech speaks on behalf of the government and the state. In the Ecuadorian presidential regime, the president speaks as head of state and government and speaks to the country, and the media cover such speeches as great agenda-setting events. Therefore, after analyzing the current information to determine the most important issues and why, the president's speeches must be written to explain what the executive's agenda priorities will be.

The president of Ecuador can deliver one of two types of speeches: a speech of investiture-the acceptance speech given by the president after winning an election, or a speech given to render an accounting of year over year progress; these occur after the investiture speech. These kinds of speeches are legally supported by the Constitution of 2008, which specifies that the executive, to obey the logic of checks and balances, has two duties, according to Article 147: "These are attributions and duties of the President of the Republic, in addition to other determined by law: a) Present at the moment of his/her possession to the National Assembly the fundamental guidelines of the policies and actions that he/she will develop during his/her exercise; b) Present annually to the National Assembly the report of achievements in relation to the National Development Plan and the objectives that the government intends to achieve during the following year". Following this logic, it can be said that according to paragraph a), the president's speech must detail what he or she will do at the time of his or her possession, while according to paragraph $b$ ), the president will explain what was done over the past year and what he or she plans to do in the future based on a past political agenda due to accountability. Both types of speeches are analyzed in this study. Correa delivered three speeches of the first type and seven of the second type.

To study the executive agendas communicated in the annual speeches of Ecuador, the Ecuadorian Policy Agendas Project, an Ecuadorian research project, analyzed the full texts of the speeches at the quasi-sentence level. This codification was performed according to the policy content coding framework created by the Spanish Policy Agendas Project (https://q-dem.com/es/) regarding the language relationships and was based on the original policy content-coding framework created by Baumgartner and Jones (https://www.comparativeagendas.net/) to investigate agenda setting in the US. An adapted codebook for Ecuador was created and based on the Spanish codebook and adapted to the mastercodebook - the codebook of the comparative agendas project-to guarantee comparability across countries.

The Ecuadorian coding system includes categories for major public policy topics (24) and for different subtopics within each of these categories, 247 (see Box 1 for details of the major topic codes). The project created a national version of the master codebook, maintaining the original categories but adding a new code (9) related to the model of development "buen vivir" of Ecuador and some subcodes to accommodate Ecuadorian reality. A particularity, the "rhetoric" code, was considered during the codification process. This reflects is a unit of analysis that could not be codified according to the proposed methodology. 


\section{Macroeconomy}

2. Rights, liberties and issues related to minorities

3. Health

4. Agrilucture

5. Labor

6. Education and Culture

7. Environment

8. Energy

9. Good living

10. Transport

12. Interior Policy and Justice

13. Social Policy

14. Housing Issues and Community Development

15. Commerce and Banking

16. Defence

17. Research, technology and communication

18. Foreign trade

19 . Foreign affairs

20. Governmental issues

21. Public lands

23. Culture

27. Climate

29. Sports

30. Death notices

Source: Elaborated by the author based on master codebook of the Comparative Agendas Project (https://www. comparativeagendas.net/).

While this last code is not mentioned in agenda-setting studies, it has been maintained here for three reasons. First, as a result of the codification, there were themes at the quasi-sentence level that were not subject to any codification because they did not include policy content, such as units of analysis where the ex-president began by telling an anecdote or ended a speech by acknowledging his team or reiterating his love for his family. Second, this code garnered the highest percentage of attention among all the speeches-more than any other issue, even those considered to have greater 
importance, such as government, economy or rights and freedoms. The third reason, and the more relevant one, is the logic that can be found just behind it.

As mentioned, the speeches were coded at the quasi-sentence level. A quasi-sentence (or policy statement) is a manifestation of a single policy idea or issue but not necessarily an entire sentence (Volkens, 2002). This component of analysis is typically identified based on the use of punctuation and conjunctions. The transcripts of the speeches were blind-coded by two researchers from the Ecuadorian team, who first determined whether each quasi-sentence contained any policy content and then assigned major topic and subtopic codes to each quasi-sentence. This system resulted in an intercoder agreement of approximately $90 \%$ in most years. The coders resolved residual dissimilarities through debate, and the project leader made the final decision when the coders could not agree. This coding procedure generated the longest known data series of executive attention in Ecuador: 10 speeches from 2007 to 2016, consisting of 3,297 entries. Because the speeches have diverse lengths, the prominence of each issue is determined not by the number of items assigned to it per se but by the proportion of the speech it consumes (Dowding et al., 2010).

To check whether the president's speeches focus on specific issues such as rights or on issues related to traditional state functions, it is necessary to measure how the attention in each speech is fragmented. As introductory results, we obtained the percentage of attention for each topic, taking into account the frequency of each topic in relation to all the units of analysis. Likewise, the average attention of each subject in relation to the 10 years of speech was obtained. Therefore, according to (Jennings et al., 2011), one indicator that can help us to understand the varying gradations of information and the average information per message is called entropy, and its typical measurement is Shannon's H (Shannon, 1948). An executive speech that concentrates on one or two issues signifies that the government's attention is dedicated to those specific issues, while one that concentrates on a diversity of issues signifies lower levels of attention. Therefore, it is possible to measure attention using Shannon's H. Applied to the present case, Shannon's H measures the probability of the government focusing attention on the issues contained within the Ecuadorian president's speech. When only one issue is covered, the probability that the government will focus attention on that issue is presumed to be 1 , and when 25 issues are covered, then the probability that the government will concentrate upon any one of them is 0.05 ; in other words, if the government's attention were equally spread across all issues, then $4 \%$ of its attention would be given to each issue. Shannon's $\mathrm{H}$ takes a probabilistic interpretation and assumes that the entropy of a structure is measured by the spread of annotations across several discrete nominal categories - the coded items in this case. The larger the entropy, the greater the uncertainty about what the government will pay attention to (Boydstun, Bevan, \& Thomas, 2014). Entropy is calculated as follows:

$$
\mathrm{H}=(-1) \sum_{i=1}^{n} \mathrm{p}\left(\mathrm{x}_{\mathrm{i}}\right) \ln \left(\mathrm{p}\left(\mathrm{x}_{\mathrm{i}}\right)\right)
$$

where the entropy scores $(\mathrm{H})$ are the negative sum of all the topics regarding the likelihood $\mathrm{p}(\mathrm{x})$ that an object $x$ (in this instance, a policy statement in the executive's speech) falls within a particular issue $i$, multiplied by the natural log of that likelihood. Logs of zero cannot be considered; therefore, 
it is assumed that $06 \ln (0)^{1 / 4} 0$ for topics where there were no policy statements in a given year. The most extreme possible entropy score for the 25 major topic codes is equal to the natural log of 25 (i.e., 25). 3.2188). An entropy score of 0 indicates that attention is concentrated in a single topic, while a score of 3.2188 indicates that attention is equally spread across all 25 major topics in such way that each issue is assumed to receive $4 \%$ of the attention (strictly speaking; that topic has a $4 \%$ probability of being the topic on which the government concentrates at any given time) (Boydstun, et al., 2014).

\section{FINDINGS}

What can we expect to find from the collected data? First, in relation to preferences, the ex-president always described himself as a person of the left, in fact, as a defender of socialism of the 21st century; therefore, it would be assumed that the executive would cover political issues related to this ideological trend, for example, civil rights and minority issues instead of others topics such as international affairs. To evaluate this, the percentage of topic attention in each speech allocated to each major topic over the ten-year span is illustrated in the graphics in Figure 1. Each issue is graphed to offer an indication of attention dissimilarities among different issues. Two issues were not considered: first, culture (which involves subtopics such as cinema, theater, music and dance, and book publishing) because it does not receive a percentage of attention, and second, sports, because it garnered only the minimum attention percentage (0.5) during 2014. The "rhetoric" code that involves narrative stories, phrases, or poems that have no political content is also considered in Figure 1.

\section{FIGURE $1 \quad$ PROPORTION OF ATTENTION TO MAJOR POLICY AREAS IN EXECUTIVES}
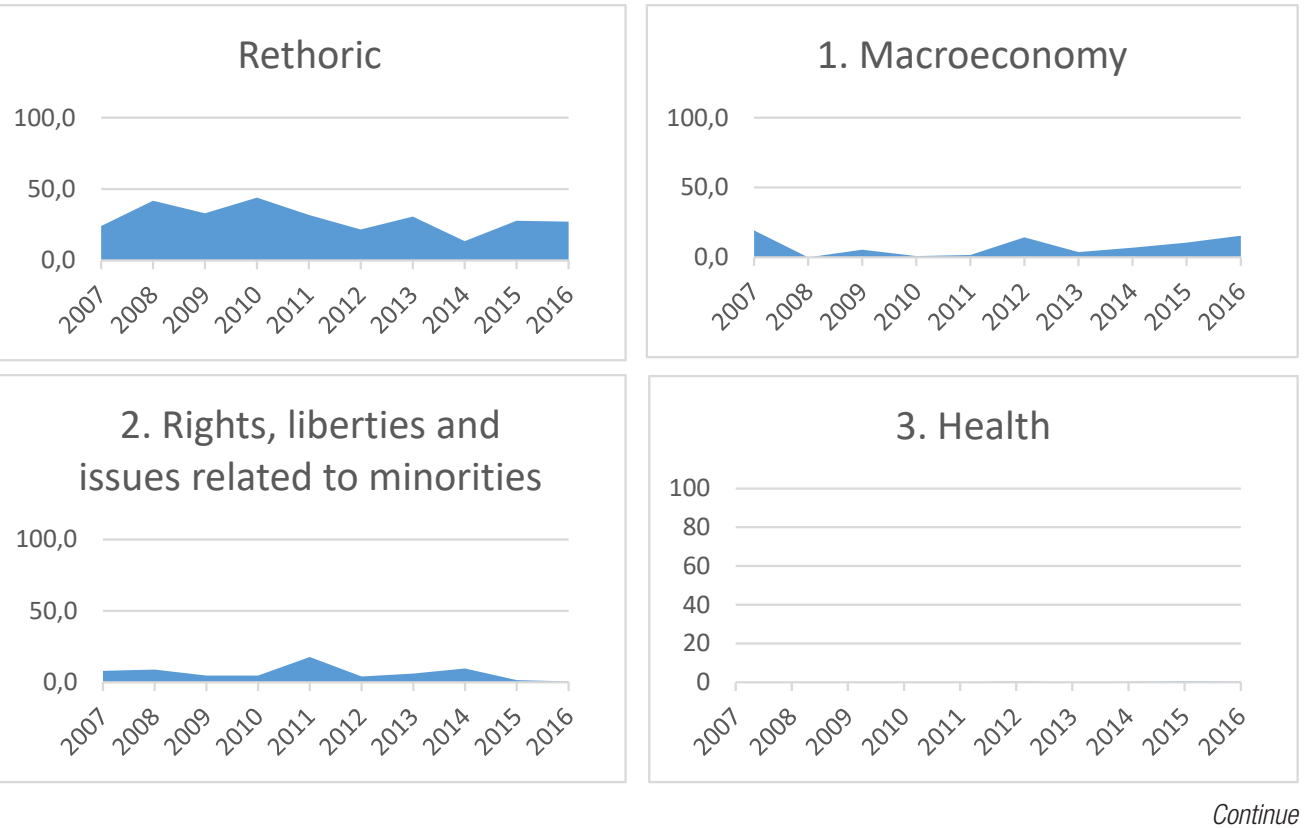
RAP | Case study: what did Rafael Correa say? Comparing political attention across 10 years of the Ecuadorian president's discourses
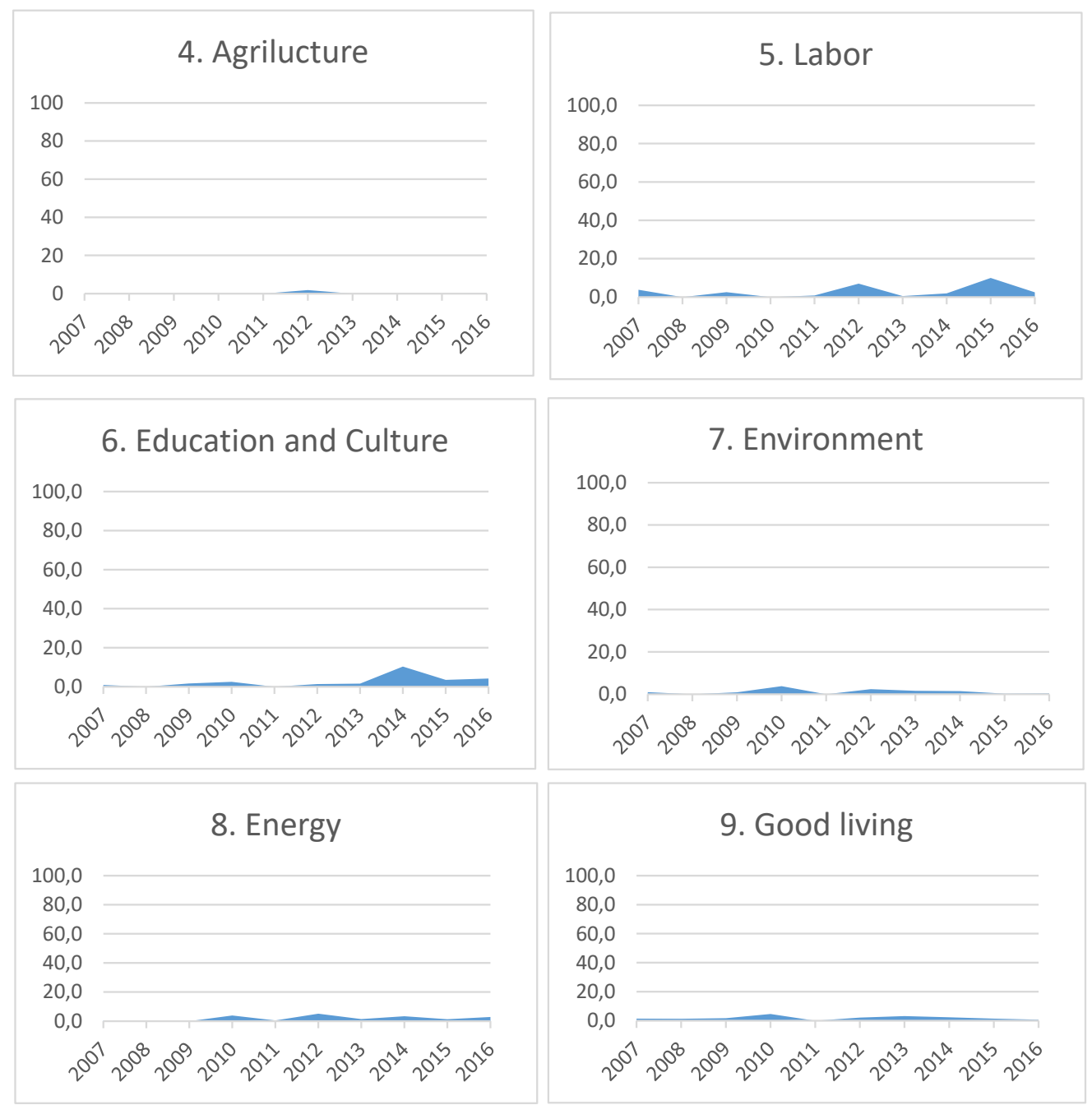

\section{Transport}
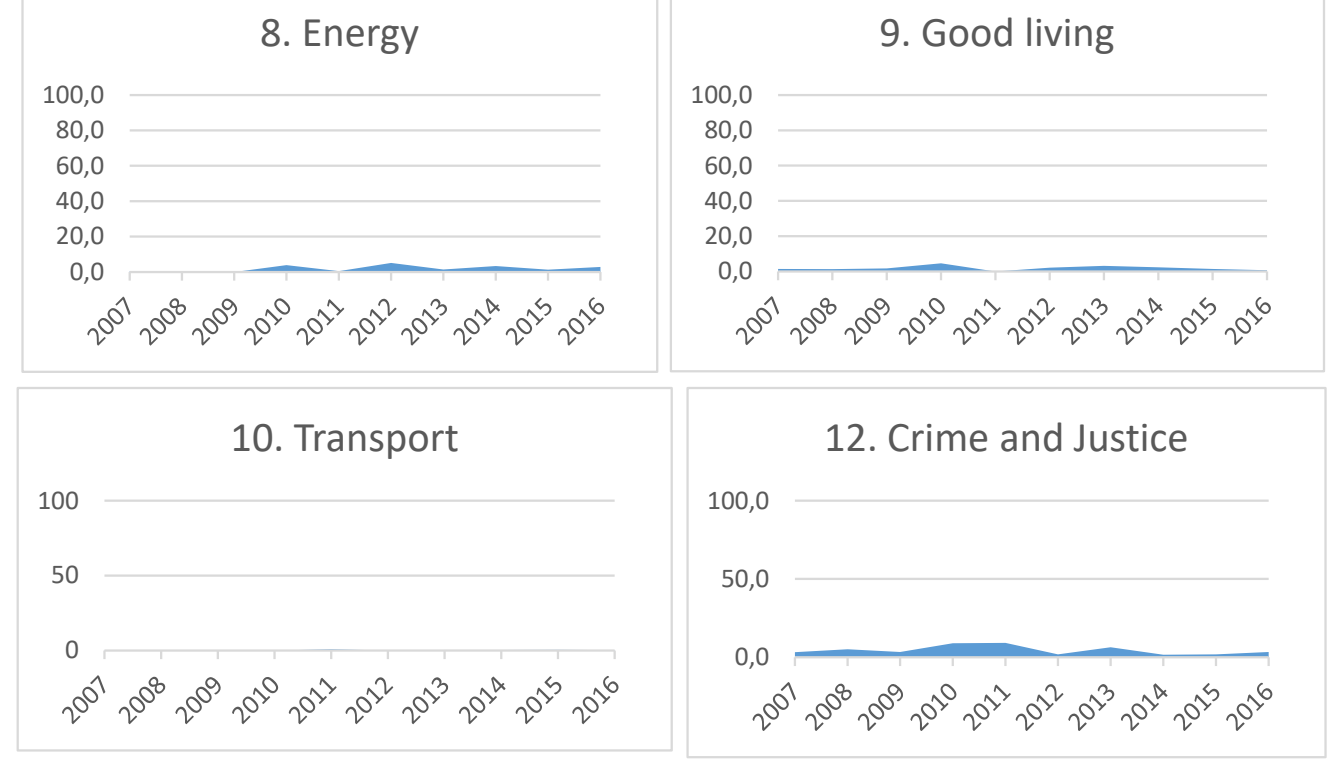

\section{Crime and Justice}

100,0

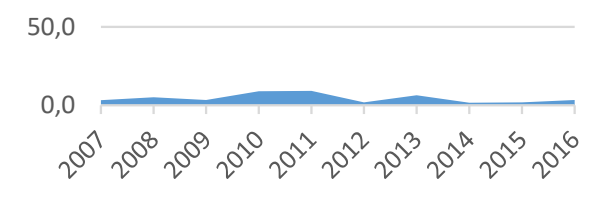

\section{Social Policy}

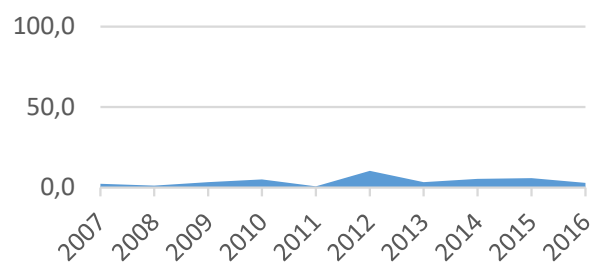

14. Housing Issues and Community Development

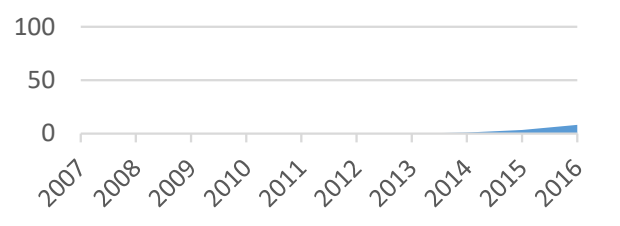

Continue 


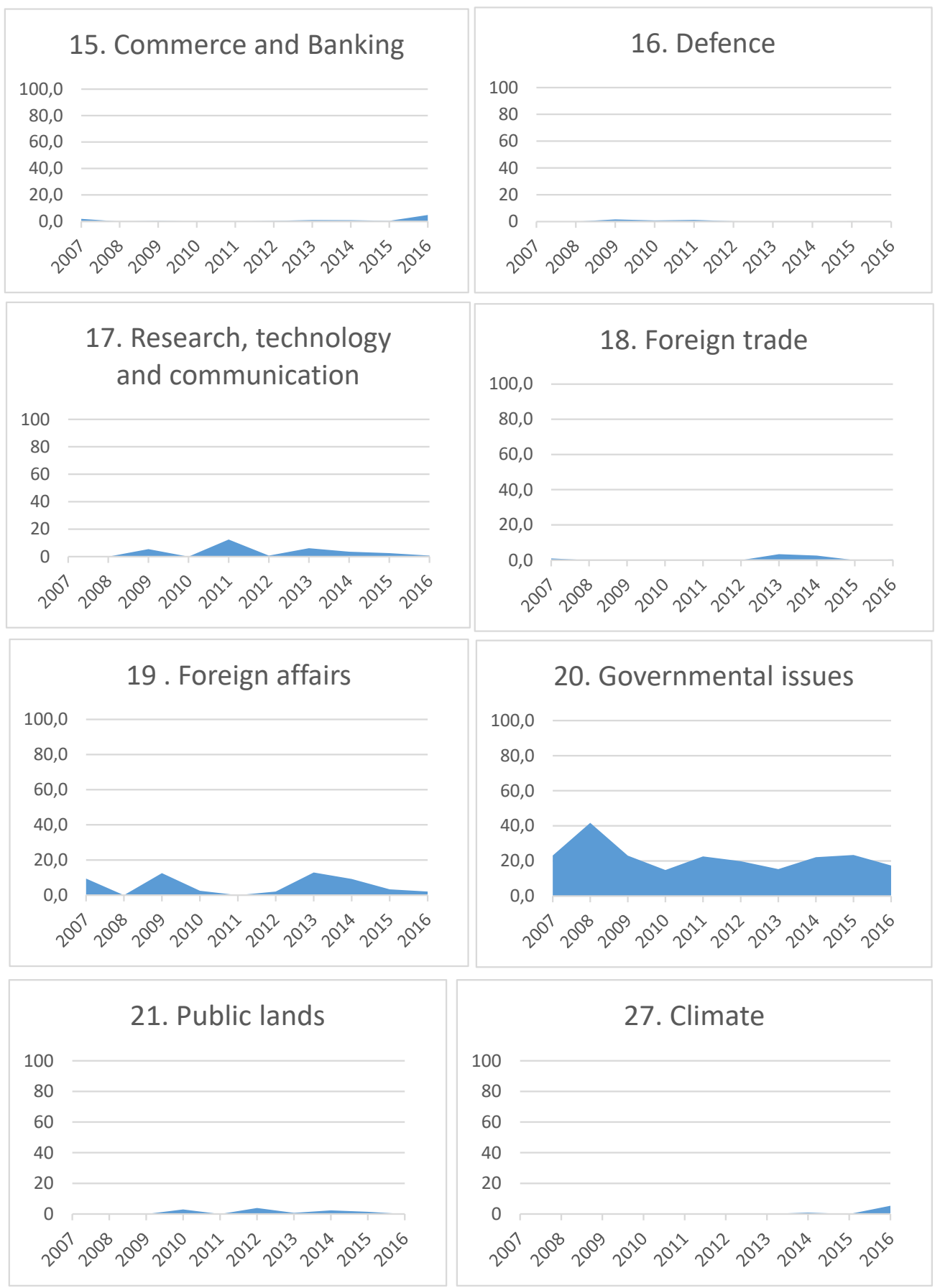

30. Death notices

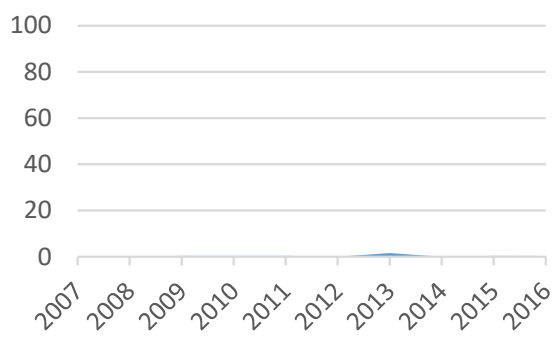

Source: Elaborated by the author based on Speeches of Rafael Correa between 2007 and 2016 . 
Based on the codebook (Table 1), some issues stand out according to the proposed methodology. Based on the calculated average coverage percentages during the 10 years in ascending order, these issues are social policy (4.1\%), crime and justice (4.5\%), foreign affairs (5.4\%), rights (6.6\%), economy (7.8\%) and governmental issues (22.3\%). The rhetoric code has the highest percentage of salience (29.6\%).

These results show that approximately $50 \%$ of the ex-president's political agenda is expended on rhetoric and government issues, and there is an abysmal gap between these and the other issues to which the president pays attention. Considering the initial expectation, on average, the executive agenda does assign less attention to foreign affairs (19) and more attention to civil rights and minority issues (2), health (3), crime and justice (12), social policy (13) and government operations (20) (Jennings et al., 2011). These findings provide support for the theoretical expectation that issue prevalence matches party preferences. It could be said that the political agenda was largely left-wing, if, for example we compare government operations (20) only with foreign affairs (19). However, comparing the first three issues, social policy (4.1\%), crime and justice (4.5\%), and foreign affairs (5.4\%), greater attention is assigned to the last issue despite the small percentage difference. What could this mean? There is also evidence that party manifestos become more complex in their issue content over time (Green-Pedersen, 2007). This denotes that when the ex-president spoke of foreign affairs, an issue that would be considered conservative according to the aforementioned study, he was really referring to a criticism, for example, of the international capitalist system or the need for the union of South American countries. Both supported by the ideology of the left. Nonetheless, under deeper analysis, it could be said that executive agendas are largely rhetorical. This finding is new compared to other agenda studies.

To explore a little further: What does the president mean when he speaks about the two left-wing issues with the biggest percentages, and what does he say when he uses rhetoric? Attention to rights, liberties and issues related to minorities is particularly high in discourse in relation to other issues. These issues were given attention over the 10-year period. During the early years (2007-2009) of his presidency, Correa talks about Ecuadorian migration and how he will work for Ecuadorian migrants through legislative representation and the National Migrant Secretariat. During his second presidency (2009-2013), the attention to this topic, particularly in the speech of 2011, grew abruptly because he focused on the issues of freedom of expression and defended the right to honor and dignity, largely due to the constant struggle that the president had with the media and his opponents and the alliance between these last two, according to the former president. What happened back then? Correa filed a complaint in March 2011 accusing the journalist Emilio Palacio and the three directors of daily "El Universo" of the crime of libel against a public authority because of a newspaper opinion piece. The opinion piece, "No to lies", refers to Correa as "the Dictator". Palacio accused Correa of "having ordered fire at will and without prior warning against a hospital full of civilians and innocent people" while a coup was taking place, according to the government, in September 2010 and concluded, "Crimes against humanity, do not forget, do not prescribe". On July 20, 2011, a Guayas criminal judge sentenced the journalist Emilio Palacio and three directors of the newspaper "El Universo" to three years in prison (El Universo, 2012). During his third presidency (2013-2017) the attention on this issue grew, for example, in 2014, when the discourse focused heavily on how the government works toward nondiscrimination against women and respect for GLBTI communities. 
Attention to governmental issues always captures most of the attention of the speeches compared to the other issues in the codebook. These issues are most prevalent in the years prior to the Constitution of 2008; after which they diminish and finally stabilize. This occurs because in the first presidency, Correa based his speech on the need for a referendum to form a constituent national assembly and then focused on justifying its work until the new constitution was enacted to propose a new state. During his second presidency (2009-2013), especially in 2011, the speeches focused on the May 7 referendum on issues related to the judicial system, security, the environment, banking and the media that favored the government's position. Finally, during the third presidency (2013-2017), the attention on this issue (for example, in 2015) concerns the democratic model of the citizen revolution, the former president's political project, which benefits the great majority.

However, the so-called "rhetoric" code has the highest percentage of attention. Its examples over the ten years of discourses involve the use of metaphors around all themes: the narration of heroic tales and myths, especially those about independence, referring to the military battles of Bolívar, Sucre and other historical figures; phrases, poems and textual quotes from other authors, such as when president quotes poems to say he does not feel hurt; governmental slogans such as "Let everything be stolen, except hope. "; cliché phrases from traditional political figures such as Che Guevara's "Hasta la Victoria siempre". Therefore, it is considered important to preserve this "rhetoric" code in the evidence and compare it in relation to the other issues. The importance of this code is that it permeates the entire body of speeches and is related to both what the president defends and what he attacks in the speeches.

Second, we test whether the president pays attention to core executive issues. One would expect that the collected data would show that the presidential agenda covers aspects such as the economy, governmental issues, foreign affairs relations, crime and justice and defense-issues connected to the functions of the State. To evaluate the issue diversity in presidential speeches, we plotted Figure 2.

\section{FIGURE 2 ENTROPY OF SPEECHES OVER 10 YEARS}

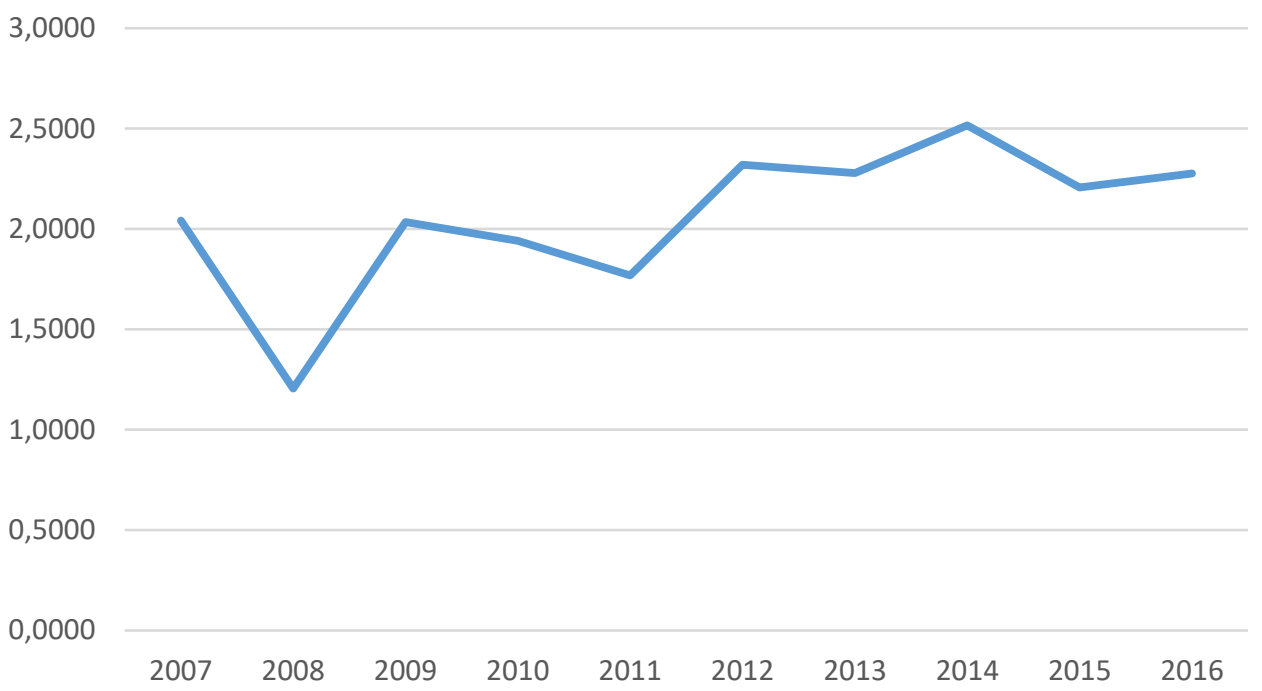

Source: Elaborated by the author based on Speeches of Rafael Correa between 2007 and 2016. 
Moving on to the effect of specific policy topics on the diversity of the executive agenda, a pattern emerges that is consistent with theory. The effect on agenda diversity is significant in three out of the five major topic codes associated with core governmental functions: macroeconomic issues (1), foreign affairs (19) and government operations (20). This significance shows that intensifications in executive attention to each of these topics lead to reduced agenda diversity. In other words, these core functions of government tend to crowd out attention to other topics, leading to a decrease in agenda diversity. When the government attends to these core issues, the share of its attention available to allocate to other issues falls. The largest reduction in diversity was observed in $2008(1,2057)$ when the president's speech focused largely on the need for the constituent assembly to agree on a new constitution. Combining these data with Figure 1, we can see that when the agenda concentrates on government issues (20) and rhetoric (both with $41.8 \%$ of attention, that is, occupying $83.6 \%$ of the agenda), issues such as economics and international relations, which are also both core issues, are omitted and gain no percentage of the attention.

In contrast, the year $2014(2,516)$ indicates an increase in diversity. This suggests that apart from the core issues on the agenda, issues such as education (6) and rights (2) are considered in the policy agenda. Combining these data with Figure 1, we can see that when the agenda is diverse due to a reduction in the attention paid to core issues such as government issues $(22.2 \%)$, the economy $(6.8 \%)$, foreign affairs (9.2\%) and even rhetoric (13.4\%), issues such as rights (9.7\%) and education (10.4\%) gain attention. For example, the issue of education is highlighted here because the government wants to emphasize how much money was allocated from the budget to education, the creation of new universities, and competitions for new teachers, among others. These findings are consistent with studies conducted on EU speeches.

Third, in relation to unplanned and external events, we should expect the collected data to show that their appearance also has an impact on the ex-president's policy agenda. Regarding economic issues (1), one of the first events that would have been considered in this section would be the 2008 economic crisis; however, this topic experienced no increase in attention. In the January 2008 speech, the president does not consider the economy as important but instead focuses on issues of government. In 2009, economic aspects appear at low percentages, but the discourse does not refer to the crisis; instead, it is based on the political position of the government's economic model, in which human beings are elevated above capital. Thus, it would seem that the president's preferences matter more than do external events.

Finally, regarding other issues such as climate (27), the code that describes issues related to natural disasters enters the president's political agenda in the speech of 2016 because on April 16, 2016, at 6:58 PM, an earthquake with a magnitude of 7.8, originating at a depth of $20 \mathrm{~km}$ and whose epicenter was Muisne (located between Cojimíes and Pedernales), killed some 663 people: 9 went missing, 6,274 were injured, and 28,775 were displaced. Some 113 people were rescued alive from the rubble (Secretaría de Gestión de Riesgos de Ecuador, 2016). This external event definitely defined some part of the executive agenda. 


\section{CONCLUSIONS}

This paper explored the policy agenda of the ex-president of Ecuador using the theories and methods applied by CAP teams in Europe and the United States to explain why some issues are more important than others and why issues vary over time. What interesting facts can we learn from the Ecuadorian case in terms of agenda-setting research?

First, we found that the most important issues coincide with those that are usually highlighted by non-conservative parties as government issues or by left-leaning parties as rights to a large extent, but right-wing or conservative issues are also covered. Thus, party preferences matter in Ecuador, nonetheless, they are also complex and do not necessarily represent the traditional difference between left and right. However, a prevalent new code appeared that was not considered in previous studies, the "rhetoric" code, which garners a greater percentage of attention than do the previous issues. The appearance of this code means that future research should also assess the impact of this code: from a framing viewpoint as cultural resonance (Entman, 1993), or from a discourse analysis viewpoint as rhetoric. Is the objective of the speech simply to be amenable to the target audience but not to maintain technical or rational content? Or is such rhetoric a common denominator, that is, part of the preferences of Latin American left parties?

Second, the president's political agenda follows the logic that core functions prevail compared to others, which means that it covers issues of government, crime and justice, the economy and external relations, as stated by Jennings et al. (2011). However, there is no mayor focus on defense, a topic that is present in European case studies. This may be because defense, especially defense in relation to other states but not internally, is currently a core function for European countries but not for Latin Americans and may occur precisely because defense in Latin America is necessary for political stability. Here too lies a direction for future research.

Third, it is clearly evident that external events are important and enter the political agenda. The 2016 earthquake allowed a different issue, climate (27), which had been absent from the president's political agenda, to enter for the second time and occupy a considerable percentage.

Finally, it is necessary to say that this empirical work establishes a first step towards a more complete study of Ecuadorian national policy agenda that will study actual legislation and media coverage of the policy agenda and will also try to verify whether the theories and hypotheses applied in the US and in Europe work in the Ecuadorian case (and of course open the door to possible comparative research between Ecuador and other Latin American countries). Following these results and ideas, some questions remain for future research, such as: Does the prevalence of the "rhetoric" code reflect a populist, left wing or presidential agenda? Are other theories applied in the US and the EU applicable to Latin American countries such as Ecuador? 


\section{REFERENCES}

Bachrach, P., \& Baratz, M. S. (1962). Two faces of power. American political science review, 56(4), 947-952.

Baumgartner, F. R., \& Jones, B. D. (2010). Agendas and instability in American politics. University of Chicago Press.

Baumgartner, F. R., \& Jones, B. D. (2015). The politics of information: Problem definition and the course of public policy in America. Chicago, IL: University of Chicago Press.

Baumgartner, F. R., Jones, B., \& MacLeod, M. C. (1998). Lessons from the trenches: Quality, reliability, and usability in a new data source. The Political Methodologist, 8(2), 1-11.

Baumgartner, F. R., Jones, B. D., \& Wilkerson, J. (2011). Comparative studies of policy dynamics. Comparative Political Studies, 44(8), 947-972.

Boix, C. (1998). Political Parties, Growth and Equality: Conservative and Social Democratic Economic Strategies in the World Economy. Cambridge, UK: Cambridge University Press.

Boydstun, A. E., Bevan, S., \& Thomas III, H. F. (2014). The importance of attention diversity and how to measure it. Policy Studies Journal, 42(2), 173-196.

Breeman, G., Lowery, D., Poppelaars, C., Resodihardjo, S. L., Timmermans, A., \& De Vries, J. (2009). Political attention in a coalition system: Analyzing Queen's speeches in the Netherlands 1945-2007. Acta Politica, 44(1), 1-1.

Budge, I., \& Farlie, D. (1983). Party competition: selective emphasis or direct confrontation? an alternative view with data. In H. Daalder, \& P. Mair (Eds), Western European party systems: continuity \& change (pp. 267-305). London, UK: SAGE Publications.

Budge, I., \& Hofferbert, R. I. (1990). Mandates and policy outputs: US party platforms and federal expenditures. American Political Science Review, 84(1), 111-131.

Canes-Wrone, B. (2001). A theory of presidents' public agenda setting. Journal of Theoretical Politics, 13(2), 183-208.
Carmines, E. G., \& Stimson, J. A. (1989). Issue evolution: Race and the transformation of American politics. Princeton, NJ: Princeton University Press.

Chaqués-Bonafont, L., Baumgartner, F. R., \& Palau, A. (2015). Agenda dynamics in Spain. New York, NY: Springer.

Chaqués-Bonafont, L., Palau, AM, Muñoz, L. y Wilkerson, J. (2008). Comparación de agendas gubernamentales: Evolución de la priorización de problemas en Estados Unidos y España.

Cobb, R. W., \& Elder, C. D. (1980). Participation in American politics: The dynamics of agenda-building. Baltimore, Maryland: Johns Hopkins University Press.

Cohen, J. E. (1999). Presidential responsiveness and public policy-making: The publics and the policies that presidents choose. Ann Arbor, Michigan: University of Michigan Press.

Dowding, K., Hindmoor, A., Iles, R., \& John, P. (2010). Policy agendas in Australian politics: The governor-general's speeches, 1945-2008. Australian Journal of Political Science, 45(4), 533-557.

Downs, A. (1972, Summer). Up and down with ecology-the "issue-attention cycle". National Affairs, 44, 38-50.

Edwards III, G. C., \& Barrett, A. (2000). Presidential Agenda Setting in Congress. In J. R. Bond, \& R. Fleisher (Eds.), Polarized Politics: Congress and the President in a Partisan Era. Washington, DC: CQ Press.

El Universo. (2012, February 17). Cronología del caso el Universo. Retrieved from https://www.eluniverso. com/2012/02/17/1/1355/cronologia-caso-universo. html

Entman, R. M. (1993). Framing: Toward clarification of a fractured paradigm. Journal of communication, 43(4), 51-58.

Green-Pedersen C. (2006). Long-term Changes in Danish Party Politics: The Rise and Importance of Issue Competition. Scandinavian Political Studies, 29(3), 219-235.

Green-Pedersen, C. (2007). The growing Importance of Issue Competion: The Changing Nature of Party Competition in Western Europe. Political Studies, 55, 607-628. 
Green, J., \& Jennings, W. (2012). Valence and Government Priorities: How issue ownership and issue salience shape US and UK policy agendas. In presentation at the Elections, Public Opinion and Parties Conference, Oxford, UK.

Green, J., \& Jennings, W. (2019). Party reputations and policy priorities: How issue ownership shapes executive and legislative agendas. British Journal of Political Science, 49(2), 443-466.

Green-Pedersen, C., \& Mortensen, P. B. (2010). Who sets the agenda and who responds to it in the Danish parliament? A new model of issue competition and agenda-setting. European Journal of Political Research, 49(2), 257-281.

Hobbes, T. (1651). Leviathan. London, UK: Bloomsbury Publishing.

Jennings, W., \& John, P. (2009). The dynamics of political attention: Public opinion and the queen's speech in the United Kingdom. American Journal of Political Science, 53(4), 838-854.

Jennings, W., Bevan, S., \& John, P. (2011). The agenda of British government: The speech from the throne, 1911-2008. Political Studies, 59(1), 74-98.

Jennings, W., Bevan, S., Timmermans, A., Breeman, G., Brouard, S., Chaqués-Bonafont, L\& Palau, A. M. (2011). Effects of the core functions of government on the diversity of executive agendas. Comparative Political Studies, 44(8), 1001-1030.

John, P. (2006). The policy agendas project: a review. Journal of European Public Policy, 13(7), 975-986.

John, P., Jennings, W., \& Bevan, S. (2010, April). Large Changes in the Agenda of the UK Government, 1911-2008: Identifying and Analyzing Policy Punctuations. In Proceedings of UK Political Studies Association annual conference, Edinburgh, Scotland.

John, P., Larsen, H. P., \& Liu, H. (2006). Comparing Executive-led Policy Agendas in the USA and UK. In Proceedings of annual meeting of the Midwest Political Science Association, Chicago, IL.

Jones, B. (2001). Politics and the Architecture of Choice. Chicago, IL: University of Chicago Press.

Jones, B. D., \& Baumgartner, F. R. (2005). The politics of attention: How government prioritizes problems. Chicago, IL: University of Chicago Press.
Jones, B. D., Sulkin, T., \& Larsen, H. A. (2003). Policy punctuations in American political institutions. American Political Science Review, 97(1), 151-169.

Kingdon, J. W., \& Stano, E. (1984). Agendas, alternatives, and public policies (Vol. 45, pp. 165-169). Boston, MA: Little Brown.

Klingemann, H. D., Hofferbert, R. I., \& Budge, I. (1994). Parties, policies, and democracy. Boulder, Colorado: Westview.

Locke, J. (1689). Two Treatises of Government. London, UK: Awnsham Churchill.

Maravall, J. (1999). Accountability and manipulation. In A. Przeworski, S. C. Stokes, \& B. Manin. (Eds.), Democracy, Accountability and Representation. Cambridge, UK: Cambridge University Press.

McCombs, M. E., \& Shaw, D. L. (1972). The agendasetting function of mass media. Public opinion quarterly, 36(2), 176-187.

Mortensen, P. B., Green-Pedersen, C., Breeman, G. E., Chaqués-Bonafont, L. , Jennings, W., John, P.... \& Timmermans, A. (2009). Comparing government agendas: executive speeches in the Netherlands, United Kingdom, Denmark and Spain. In Proceedings of $2^{\circ}$ Annual Meeting of the Comparative Policy Agendas Conference, The Hague, The Netherlands.

Mortensen, P. B., Green-Pedersen, C., Breeman, G., Chaqués-Bonafont, L., Jennings, W., John, P.... \& Timmermans, A. (2011). Comparing government agendas: Executive speeches in the Netherlands, United Kingdom, and Denmark. Comparative Political Studies, 44(8), 973-1000.

Petrocik, J. R. (1996). Issue ownership in presidential elections, with a 1980 case study. American journal of political science, 825-850.

Rousseau, J. J. (1762). The Social Contract. France, Paris: Penguin Books.

Schnattschneider, E. E. (1960). The semisovereign people. New York, NY: Holt, Reinhart and Winston.

Secretaría de Gestión de Riesgos de Ecuador. (2016). Informe de situación $N^{\circ} 71$-Terremoto 7.8 Pedernales. Retrieved from https://www.gestionderiesgos. gob.ec/wp-content/uploads/downloads/2016/05/ INFORME-n71-SISMO-78-20302.pdf 
RAP | Case study: what did Rafael Correa say? Comparing political attention across 10 years of the Ecuadorian president's discourses

Shannon, C. E. (1948). A mathematical theory of communication. Bell system technical journal, 27(3), $379-423$.

Volkens, A. (2002). Manifesto Coding. Berlin, Germany: WZB.
Walgrave, S., Varone, F., \& Dumont, P. (2006). Policy with or without parties? A comparative analysis of policy priorities and policy change in Belgium, 1991 to 2000. Journal of European Public Policy, 13(7), 1021-1038.

\section{Pablo Ruiz Aguirre}

https://orcid.org/0000-0002-1504-7544

M.Sc. in Governance, Policy and Political Economy; Associate Professor in Faculty of Law at Universidad Internacional del Ecuador (UIDE). E-mail: paruizag@uide.edu.ec 